\title{
Librarian's Information Literacy Skills to Fulfilling Library Users' Needs A Public Library in Bogor, Indonesia
}

Paper Type:

Research Paper

Alfia Hasanah and Margareta Aulia Rachman

Universitas Indonesia

\section{Abstract}

Background of the study: literacy skills of librarian

Purpose: This study aims to identify the information literacy skills of librarians in meeting the information needs a user at the public library in the city of Bogor. Method: This study used a qualitative approach with the case study method. Data were collected through observation and interview. The informants of six people selected using purposive sampling, with the criteria set librarian of Library Science education. Information literacy models used in this study are a model Empowering Eight, consisting of identification, exploration, selection, organization, creation, presentation, assessment and application information. .

Findings: The results showed that the information literacy librarian at the public library in the city of Bogor in meeting the information needs user already applied include a component on the identification, exploration, presentation, assessment, and application.

Conclusion: There are some capabilities that cannot be applied to the maximum, including component selection, organization and creation of information.

Keywords: information literacy, user needs, librarians, public libraries
Submitted 07 December 2018 Accepted 30 April 2019

Online 30 September 2019

* Correspondence : Alfi Hasanah E-mail: alfiahsnh@gmail.com 


\section{Introduction}

Information literacy is an important aspect for a person to achieve the goal of education, employment, personal or social objectives (Catts, 2010). Consciously or unconsciously man certainly needs information to support their daily activities. It is therefore not surprising that the information is considered to be the main needs of each individual and to be important for everyone without exception. The importance of information literacy is increasingly associated with changes in technology and the rapid proliferation of sources of information. According Assocation of College \& Research Libraries (ACRL), the meaning of information literacy is a set of capabilities that are needed someone to recognize when information is needed and have the ability to locate, evaluate and use effectively the needed information. Various information coming constantly and turns into the human memory. This leads to the phenomenon of the explosion of information, where the information provided numerous. A person who has the information literacy skills can know how to access, format, and when it uses (Armstrong, 2004). To prevent people trapped in such a situation, it should institute or information services should serve to provide quality information services. The information agency one of them was a library. A person who has the information literacy skills can know how to access, format, and when it uses (Armstrong, 2004). To prevent people trapped in such a situation, it should institute or information services should serve to provide quality information services. The information agency one of them was a library. A person who has the information literacy skills can know how to access, format, and when it uses (Armstrong, 2004). To prevent people trapped in such a situation, it should institute or information services should serve to provide quality information services. The information agency one of them was a library.

One voice library information literacy is a public library in the city of Bogor. This is indicated by the information literacy program aimed at users, namely Pustakaloka Travel Program. Based on the vision and mission of the public library in the city of Bogor as a source of information, then it should have a library as an information services provider agency must be able to accommodate the needs of user information. Librarians also responsible for empowering user to train their ability to obtain and use information effectively, efficiently and ethically. This is evidenced by a study entitled Librarians Role in Development and Achievement of Central Library Users' Information Literacy (A Case Study: Iran) by Yaminfirooz (2013), which showed 52, 7\% user judge that librarians are very influential on the development of their information literacy as user and $44.7 \%$ said that they have acquired the literacy skills of librarians information not from others. In addition, the role of public libraries as lifelong learning is a major concern of the local government on the development of the public library in the city of Bogor in the era of information explosion of information and as it is today.

Based on that librarians as a driver library needs to have the literacy skills to process information in order to meet the information needs user. According Wicaksono (2016), which controls the information literacy librarian will be able to determine their information needs, find information based on their needs, evaluate the information found, and use information in accordance with applicable regulations.

The Bogor City Public Library was chosen for study because the library has not had a program that can maximize the capabilities of information literacy librarian. In addition, researchers want to raise the problems that arise in the implementation of information literacy librarian at the public library that is still very minimal studied. Based on this, the research was conducted to determine how information literacy librarian at the public library in the city of Bogor in meeting the information needs user. This study is expected to provide an overview understanding of information literacy librarian, librarians, especially public libraries serve the information needs in relation user.

The results of research and discussion is presented in narrative form by using a model of information literacy Empowering Eight as a benchmark in this study. Eight Empowering models considered suitable applied in developing countries due attention to local conditions and cultures, namely the condition of Asians. This model not only can be applied in the context of education, but also can be applied to address the information in the world of work and daily activities (Wijetunge,

To cite this document:

Hasanah, A., Rachman, M.A. (2019). Librarian's information literacy skills to fulfilling library

users' needs a public library in Bogor, Indonesia. Record and Library Journal, 5 (1), 22 - 32 . 
2009). Steps owned Empowering Eight also be directed to things that are more specific than the other models.

\section{Method}

The approach used in this study is a qualitative approach. The method used is the case study method. Informant selection technique in this research is purposive sampling based on the objectives and specific considerations. Therefore, the researchers determined the criteria informants in this study, the manager of the public library in the city of Bogor that have an educational background of Library Science. Based on these criteria, the obtained six informants accordingly. Name changed to protect the identity of informants informants. Here is an informant of data used in this study:

table 2.1 Data Informant

\begin{tabular}{|c|c|c|c|c|}
\hline No. & Name & office & Part & Education \\
\hline 1. & Cherry & $\begin{array}{c}\text { Librarian } \\
\text { implementing } \\
\text { advanced / } \\
\text { proficient }\end{array}$ & $\begin{array}{c}\text { Staff } \\
\text { Procurement, } \\
\text { Processing and } \\
\text { Preservation of } \\
\text { Library } \\
\text { Materials }\end{array}$ & D3 Library \\
\hline 2. & Mirna & $\begin{array}{c}\text { The first expert } \\
\text { librarians }\end{array}$ & $\begin{array}{c}\text { Staff } \\
\text { Procurement, } \\
\text { Processing and } \\
\text { Preservation of } \\
\text { Library } \\
\text { Materials }\end{array}$ & S1 Library \\
\hline 3. & Tati & $\begin{array}{c}\text { The first expert } \\
\text { librarians }\end{array}$ & $\begin{array}{l}\text { Staff Service, } \\
\text { Automation and } \\
\text { information } \\
\text { networks }\end{array}$ & S1 Library \\
\hline 4. & Dedi & $\begin{array}{l}\text { candidates } \\
\text { inpassing }\end{array}$ & $\begin{array}{l}\text { Staff Service, } \\
\text { Automation and } \\
\text { information } \\
\text { networks }\end{array}$ & $\begin{array}{l}\text { S1 Library } \\
\text { S2 } \\
\text { Communications }\end{array}$ \\
\hline 5. & Febi & $\begin{array}{l}\text { candidates } \\
\text { inpassing }\end{array}$ & $\begin{array}{l}\text { Coaching Staff } \\
\text { Library and } \\
\text { Reading Interest } \\
\text { Development }\end{array}$ & $\begin{array}{l}\text { D3 Library } \\
\text { S1 } \\
\text { Communications }\end{array}$ \\
\hline 6. & Jesika & $\begin{array}{c}\text { Librarian } \\
\text { associate expert }\end{array}$ & $\begin{array}{l}\text { Coaching Staff } \\
\text { Library and } \\
\text { Reading Interest } \\
\text { Development }\end{array}$ & S1 Library \\
\hline
\end{tabular}

The process of collecting data in this study will be carried out by means of observation and interviews. After all the data is collected, the data were analyzed by using data reduction, data presentation, and conclusion.

\section{Result and Discussion}

1. Profile Bogor City Public Library. Bogor City Public Library as one of the centers of learning (learning center) in the city of Bogor, seeks to contribute actively in the effort to build interest and reading habits of people in Bogor. This library has a service that is open (open access) and provide services for the user which is located away from the library to provide mobile library services. Bogor City Public Library in meeting the information needs of a user presents a collection of general

To cite this document:

Hasanah, A., Rachman, M.A. (2019). Librarian's information literacy skills to fulfilling library

users' needs a public library in Bogor, Indonesia. Record and Library Journal, 5 (1), 22 - 32 . 
literature, reference books, children reading books, and to meet the needs of the information is up to date available is also a collection of daily newspapers and magazines.

Based on the vision and mission of the library as a source of information, then the library as an information services provider agency must be able to accommodate the needs of user information. To accommodate and meet the needs of user information originating from various circles, it is necessary librarians have the information literacy skills so that helps librarians can play its role to guide and create a knowledgeable society Bogor City.

2. Understanding of Concepts Regarding Information Literacy Librarian. Understanding of information literacy can be seen from the answers to the informant about the concept of information literacy applied in his work as a librarian to meet the user information needs. Based on the National Library of Regulation No. 11 of 2015 on Technical Guidelines for Functional Librarian, one librarian's task is to provide library services through activities provide guidance and library services and information to user. Therefore, librarians as a user mentor in finding the information needed to understand the concept of literacy information. This this is expressed by the informant.

"The information literacy emm ability to search for, identify, evaluate, to use such information in accordance with the needs of users. "(Tati)

According Zurkowski, an information-literate person is a person trained to use sources of information in completing tasks for them (Eisenberg, et al., 2004). Informants aware that the information literacy skills support their work in meeting the needs pemustaka.

"Apart from the librarian or not, every human being must always relate to information, especially us who work in agencies such as the library field information and here indeed requires us to be able to apply more that information literacy. So I think it is very important, because we are in need of information on literacy where it is needed. "(Tati)

Understanding of the information literacy librarian mastered is the result of the learning process and increased oversight over the librarian at the public library in the city of Bogor. When they are not familiar with the concept of college is because the information literacy courses taught especially in Library Science. Because the average librarian at the Public Library of Bogor undergoing a period of study at the beginning of the 1990s, while the concept of information literacy in the library emerged around 1997. However, based on interviews showed that the informants have an understanding of the importance of literacy in the library for user.

3. Capability Model Based Information Literacy Librarian Empowering Eight. Based on the model of information literacy Empowering Eight, consisting of eight stages, namely the ability for identifying, exploring, selecting, organizing, creation, presentation, assessment, to implementation of the information. Each component has a demonstrated learning outcomes.

1. Identification (Identify). A). Identifying topic / subject

Identify the topic or subject is an important step in order to determine and limit what information is needed. This is in accordance with the statement of the Association of College \& Research Libraries (2000), that the first stage performed by a person whose information literacy is to determine the scope of the information required, it is useful that the information obtained can be controlled and focused. This is in line with the informant statements that reflect that they have been able to recognize and identify the topic / subject information based on the user information needs.

"...if mothers most ask novels or cookbooks and other applied sciences, if the children are looking at a lot of novels and literature, if that is doing research grade 00 usually find books about research methodology. If employees who are looking for lots of information about the computer, such as the use of excel, word, basic typing. Because bygone era as computer literate as now, yes, so maybe they feel difficulty because the work is now required to use the technology. Then reply to the subject of the

To cite this document:

Hasanah, A., Rachman, M.A. (2019). Librarian's information literacy skills to fulfilling library

users' needs a public library in Bogor, Indonesia. Record and Library Journal, 5 (1), 22 - 32 . 
most requested hell about psychology, religion, equal educational yes. Many also wondered information regarding the history of Bogor and find whether there is a book related to the city of Bogor. "(Febi)

Needs someone different information that is influenced by the role that they live in a life and their environment. It is influenced by the type user public library is diverse, ranging from students, students to the general public such as housewives, civil servants and pensioners. As for how the informants recognize and identify the information needs user in various ways as viewed from the questionnaire, the proposals demand books, borrowing or collection database are read, and the most common of the six informants do is to verbally or ask translation directly to the user. Based on the answers of informants, show that they do determine the topic / subject based on the user information needs before doing the search information.

B). Identifying Keywords in Finding Information Needed. Once you understand what information is needed, the next step is to identify keywords that can represent the information content to be searched. Based on the research results, the informant can identify keywords first before performing a search of information. The identification of keywords is done by topic or subject is determined based on information and deepen the topics to be more specific for information retrieval.

C). Planning for Information Search Strategy. Preparation of the plan in search of information is very important to go to the source and the information sought is relevant. The purpose plan is set out the steps to be performed when searching information. Here expression informant:

"No strategy or plan, heck if I still spontaneously wrote. "(Cherry)

"No spontaneous heck I immediately wrote. "(Mirna)

"Spontaneous wrote it, so adjusted user what information needs ... "(Smith)

"Spontaneous. If the strategy does no important when browsing it, we know science knows and coherence. "(Jesika)

How to search for information made by the informant relatively the same, namely the search manually by searching the collection directly on the rack, a search using an electronic database that was built by the library, and also search by means of direct access to databases that exist outside the institutions, either by means of or the internet network. Despite the fact that they run such a strategy, but it is undeniable that they did not do the planning first.

4. Determining Resources Used. The librarian should be able to determine the source of information that can meet the information needs user. Based on Law No. 43 Year 2007 on the Library in Chapter V, Article 14 states that "every library develop library services in accordance with the advancement of information and communication technology". Therefore, librarians charged with the development of ICT adaptive to the needs of information services for users. This is in line with the answers of informants, in addition to using a variety of resources in print, they also use online resources.

"We most find that information quickly wear-out. Or for example, user say find a book on how to grow watercress, if we already know well the subject of information they are looking for and already know what class, I am more inclined to invite directly looking into the dinghy on the shelf .... Apart from my book also usually find information on Google yes, because it is more effective. I now also have ebook of the National Library (iPusnas) it, so I also used to get and read from it, usually we can borrow 3 days. "(Jesika)

"I usually find that information, refer to the first catalog no title or subject of the information I was looking for what no, whether of general work books, reference books, articles. If my new not looking on the internet via Google, I also choose access to the National Library website. "(Febi)

Based on the interview in identifying sources of information, informants can choose and utilize a

To cite this document:

Hasanah, A., Rachman, M.A. (2019). Librarian's information literacy skills to fulfilling library

users' needs a public library in Bogor, Indonesia. Record and Library Journal, 5 (1), 22 - 32 . 
variety of resources available both printed sources in the library as well as online resources on the internet. Librarians are already very familiar with using the library OPAC. This shows that they have the ability to understand and identify the resources needed for with just finding information is not enough.

2. Exploration. A). Finding Information In accordance with a Topic. At this stage contains a variety of ways in which the informant to find information. The sources of information used should be relevant to the information needs. The title, abstract and table of contents is the part that should be seen first when determining the subject or topic of information. This is expressed by the following informant.

"Most sought essentially yes, for example, read from the abstract or conclusion only appropriate and contains what we were looking for. We are looking for some information from various sources as well in order to compare. "(Mirna)

Based on the results of the study, after knowing the subject of an information, to determine what information is really needed by user, librarians need to read the entire contents of the information. But do not stop there, the user was not satisfied and did not quite find the source of the acquired information, they use more than one source of information to meet the needs of information. After the librarian to get information from various sources, and they can do a comparison to determine the most appropriate information to the topic or need the information they seek. It shows informant was able to find the information that corresponds to the topic and is able to compare the information obtained more than one source of information.

B). Conducting interviews, field visits, or training for Obtaining / Completing Information. Furthermore librarians who are considered to have the literacy skills of information according to the model Empowering Eight one of which is to explore the information by conducting discussions or interviews, field visits, training or other outside research so that they can study and complete the required information. Discuss the need for information will increase knowledge of librarians in terms of meeting the information needs. With so they can exchange ideas on the information needed.

"Yes, fellow librarians usually we love ngobrolin gather information burgeoning also be able to add the information that I have or that I need. Most, if we also want to ask or discussions with district librarians in public libraries. "(Mirna)

In addition to discussions, librarians also need to know the availability of information in the public library in the city of Bogor. In addition, librarians should be aware of the source used to find information. As well, librarians need to determine whether or not enough information is available to meet the needs of information. If you need to make a visit or study visits to other libraries then should it be done to obtain or add the appropriate information.

"If for a comparative study, we normally to the National Library of Indonesia, to the Library, the Library Board to pusipda Bandung. "(Mirna)

In addition to discussions or interviews and visits to other libraries, that can be done to obtain or add to the information required by way of training. This type of training obtained librarian of the Library of Bogor and preservation of library automation system of the National Library of the Republic of Indonesia. Librarians have had discussions with others that mates profession to get and add the needed information. The informant also stated that the discussions, external visits, or training is an important thing in order to improve the accuracy of the information obtained and to develop competencies themselves as librarians. Nevertheless, activity or study visits and training are still rare.

\section{Screenings (select). A). Selecting Relevant Information}

One of the components in the selection is the ability to be able to perform the source selection information so that the information obtained is actually relevant, trustworthy and meet the information needs. Selection of resources obtained through the website domain is most convenient to specify the 

information that we get if the information is accurate or not.

"Yes, it is selected. Yeah, it if Google was like a lot of campaign ads so yes, usually the heck I avoid web sites such as if there are ads that usually definitely dong the information provided that accentuate their products, for example, is rich in personal blogs. If I liked best about health news read on the web that is already credible detik.com, rich, healthy so what ya I forgot. Noheck, I still find information via the Internet if not checking the refence list, I read only. "(Cherry)

Informants above suggest that the importance of seeing the domain of resources, but not for other informants. They use all domains for information. It cannot be denied that in the search for information in search engines, like Google does produce a lot of information from websites that are less reliable accurate. According to two informants, sources of information were used only be used as material for her to get preliminary information about the information they are looking for and become a bridge just searching printed resources to obtain accurate information.

Answers librarian in response to a question at this stage is to check the website domain, check back capability authors and publishers, as well as pay attention to the novelty of the information. Librarians show that they have been able to select the accuracy of the information they can with the goal of selecting the relevant information needed.

B). Noting Relevant Information. The next component in the stage of selecting the information obtained is recorded or collect the relevant citations. Making the record is a little thing, but a thing that can be useful in the future to rediscover the information has been obtained. It is as expressed by the informant by collecting important information by way of an outline created and compiled with Microsoft Word tools to capture important information

"Yeah, sometimes I record anyway, the information that I think is important I made the outline note as that. "(Mirna)

"Yeah collects I type made (Microsoft) Wordnya. "(Febi)

The development of technology at the time was very helpful informant. Mobile is a tool used them to gather important information is found to be more easily retrievable by means of photographing or me-a screenshot of the information.

"Yes noted before, citing the important information wrote normally. But sometimes recorded or photographed sometimes only. "(Smith)

Based on this research, the informant was able to collect quotations or important information to facilitate rediscover information has been obtained.

C). Identifying Stages Process. Based on the result, not all the informants who are able to make and identify the stages of this process. This suggests that the ability to identify the stages of the process undertaken to select the appropriate information was not even owned by librarians.

4. Organizing (Organize). A). Grouping Information. One component in the organization is the ability to be able to classify or sort the information that has been obtained. Based on the research results, ability grouping information that has been obtained by the Public Library librarian Bogor City is still lacking, reflected in the results which showed that only two people who have been able to do grouping that information. This can lead to information that can accumulate or get flooded and difficult to find this information again when later needed back. As a result, the process of search and discovery information to be ineffective.

B). Information Distinguishing between Fact and Opinion. The next capability in the organization is the ability to distinguish between facts and opinions from the information obtained. As expressed by the following informant.

"If the source is certainly clear from the fact that the main source, if opinions are usually words that are processed again already more enhancements. If hoaxes that, from the beginning I was

To cite this document:

Hasanah, A., Rachman, M.A. (2019). Librarian's information literacy skills to fulfilling library

users' needs a public library in Bogor, Indonesia. Record and Library Journal, 5 (1), 22 - 32 . 

referencing or searching credible sources of information already just let me avoid hoax, so I suggest to user access credible and official sources. "(Smith)

Based on the interview, show informants can distinguish between facts and opinions. The informant stated that the fact is the information that is based on existing data, based on reliable sources of information, and course information of the parent or primary source. The informant stated that the opinion in the form of opinions or quote information that can be viewed in terms of the existing language additions and uncertain truth.

C). Checking Presence Information Obtained Bias. Elements that do informant in doing this checking is by comparing the information in other sources. This is done when finding any doubt or error information obtained at the source, then it could have been verified by comparing it with other sources of information so that the information obtained is not only appropriate but also logical. As disclosed below informants who do not just rely on one source for information that really appropriate and logical.

"Yes I compare, so I am unsure of the information I found on the internet, for example, then I compare the website, in the article, or a book. "(Mirna)

Librarians answer questions in this component by checking back and compared with information in other sources. This process is performed to obtain the appropriate logical information with user needs.

5. Creation (Create). A). Develop Information Obtained. At this stage, the best information that has been selected in the previous stage began to put together and arranged to be new information that can address and meet the needs of information. One librarian's ability at this stage to know whether they've been creating works that have been published or unpublished. In the creation phase is expected librarians can create new information. Of the six informants, only one ever to create works that have been published.

Most librarians answered questions in this component by making posts or new information by arranging information and stringing with his own words according to the context. But most librarians can not create a new information in written form and is still limited to it verbally. This suggests that the ability of librarians created the information is still low due to the interest and habit of writing is still minimal among librarians. So that the information obtained in the form of written work still needs to be improved.

B). revising Information. Criticizing the information is important. The development of knowledge and misinformation contained in resources may occur. The critical attitude can cause a reaction in the form of the ability to revise the information.

"...so far has not been on the revision stage discussions with others about my writing it because it was for personal consumption as well. "(Tati)

Based on the answers of informants, most librarians still do stage revise the information. This shows that individual behavior can be seen from the lack of ability to think critically about the development of the information.

C). Reference Source Lists. According Modules Information Skills actions considered as plagiarism is stated writings of others as his own works and quoting others directly without including the original source. Three informants understand plagiarism is unethical, therefore they are always specifying the source of reference in his writings. This was done to compare information from various sources, appreciate the work of others and as reference material to facilitate retrieval when it is needed.

"Yes. If I always write down the source, created a list of libraries such as making paper wrote. So I write down the source of the statement or the statement that I quoted clearly. Because writing was an important reference source yes. First, as reference material when it is needed back. Second, I think it's ethical to write a paper yes, when it is not a statement that came out of our personal and it quotes from

To cite this document:

Hasanah, A., Rachman, M.A. (2019). Librarian's information literacy skills to fulfilling library

users' needs a public library in Bogor, Indonesia. Record and Library Journal, 5 (1), 22 - 32 . 

others should be included, as we attempt to appreciate the writer as well. "(Tati)

However, because there are many informants who have never created the papers, so they have not implemented the stages listed the source of reference when creating the work itself and merely convey information orally. This is because they are unfamiliar with the oral culture with yet familiarize and developing her ability to write. Based on the interview, the informant generally only knows the inclusion of a reference source that is important, but the application of knowledge of how to prevent plagiarism and how to use information ethically still not good.

6. Presentation (Present). A). Practicing Presentation Information. Information literacy librarian at this stage to see if librarians use information effectively by way of presenting it to others, especially to the user. Having the information should not be buried for personal consumption only, should be communicated to others to the knowledge of others and self-improvement information. Informants choose to submit information directly to explain verbally to user in the form of guidance or presentations.

"I relayed verbally immediately wrote to user. "(Cherry)

"If my user to verbally communicate directly wrote. I've also presented information to many people in the form of a presentation so resource on library management. If work or family friend to be able to share directly face to face .. "(Jesika)

At this stage of the presentation of information, the informant stated Jesika has been a guest speaker in the activities of the library. He presents information in front of people by using the method of presentation. In addition to the oral form, the presentation of the information provided librarians can also be in the form of hardfile the form of a printout and also softfile.

B). Media Used to Share Information with Others. In conveying information to others should be done in the right way of communicating information which must be accompanied by the ability to choose the right media in the dissemination of information. Communication is not only can be done orally and face to face, but also through writing and indirectly. Informal communication activities carried out by almost all the informants more done in written form that is through the internet. In this case the use of social media is a form of communication in writing to another person, both to user, colleagues or family. Librarians should certainly be able to take advantage of a variety of existing communication media for various purposes. Especially to interact with others in order to maximize service to users.

"If for example the internal environment with family or fellow librarian delivery of information I can say in social media groups, for example WA or Facebook and others. "(Tati)

Based on the answers given by the informants, in addition to presenting information orally and face to face, but they also take advantage of social media to communicate information to others. So in this component can be categorized informant already have the ability to choose the right media in conveying information.

7. Ratings (Assess). A). Receive and response Comparing Based Self with Others. One component at this stage is the ability to receive and compare the responses based on their own assessment to others. Accept criticism and suggestions from others is crucial for the construction and development of information to himself. Based on the interview, all the informants revealed that they receive any feedback in the form of criticism and suggestions.

"If the response is no hell, at least just a good shot just that. If the criticism does not yes. But I thank lets get feedback or input from others. Evaluation materials as well for us. "(Smith)

Their criticism and suggestions can be used as material for evaluation to promote the appreciation and repair work, so it will be motivated to improve and enhance the services that user satisfied. The whole answer informants in accordance with the learning outcomes demonstrated that librarians are able to accept criticism and suggestions from others gracefully and comparing the criticisms and

To cite this document:

Hasanah, A., Rachman, M.A. (2019). Librarian's information literacy skills to fulfilling library

users' needs a public library in Bogor, Indonesia. Record and Library Journal, 5 (1), 22 - 32 . 
suggestions. That means, librarians have been able to do introspection on the performance as well as feedback and ratings from others. In addition, the librarian replied that they take notes and use the criticism and feedback to make improvements, make it as an evaluation for the future.

B). Assessing Performance in Meeting the Information Needs Self user. A librarian must also be able to develop professionalism on an ongoing basis with a reflective action on the duties and functions in which they live. This is done by assessing the performance itself continuously. By assessing the expected performance they can continue to improve the role and responsibility as a librarian. This assessment is not necessarily done by the library formally, but it can also be done individually by yourself. In addition to seeing the response from user, informants can also assess the performance itself from the superior evaluation. When he gets the credit for the success of the performance run will amount to the satisfaction for having to serve and meet the information needs user.

Based on the answers of informants, they have been able to reveal the shortcomings they had and reflect on how far the success of the performance itself. It can be concluded that they have been able to assess the performance of himself in an effort to meet the user information needs. Then the results of the assessment were utilized to make efforts to repair and improve the professionalism. Of course, also the librarian should be able to keep abreast of developments and continue to learn from a variety of sources and ways.

8. Implementation (Apply). A). Applying Information for Different Situations. Application information can make someone aware that the information in its possession can be used for various situations in life. According Soemardjan in Herman (2000) on the use of information can be divided into two groups of consumer information and information capital.

Consumer information is useful consumer information that can be enjoyed directing. It is as expressed by informants who may apply directly acquired information from the Internet and books.

"If I need more information about cooking, I find on google and in cookbooks, and I read and get the information. I went home and I practice that cuisine. So that means if I get the information that relate to the needs of my life can be immediately applied in everyday life. "(Tati)

While capital information is information necessary for the production process to prepare an outcome, so that still need processing.

"Practiced, for example, we got information about managing the library, we can apply in our work lives. If the information I can from the usual user incidental information if relevant also to the needs of the family. "(Jesika)

Based on the answers of informants, show that they can apply to the processing of such information in advance to be used in everyday life.

\section{Conclusion}

Based on the research of information literacy librarian at the public library in the city of Bogor can be concluded that the information literacy skills of librarians in terms of satisfying the information needs user already applied to the component identification, exploration, presentation, assessment, and application. However, there are some capabilities that can be said cannot be applied to the maximum, including component selection, organization and creation. Information literacy becomes an important capability that is owned by librarians. Understanding of the information literacy librarian mastered is the result of the learning process and increased oversight over the librarian at the public library in the city of Bogor.

The preparation of the information literacy program for librarians Bogor City Public Library needs to be done, particularly regarding the ability of selection, organization and creation of information held by people who are competent in this field. Training can be done in the form of training and seminars or workshops. The librarian should be able to develop her skills, such as improving the reading culture in order to broaden the knowledge and the power to think critically, to

To cite this document:

Hasanah, A., Rachman, M.A. (2019). Librarian's information literacy skills to fulfilling library

users' needs a public library in Bogor, Indonesia. Record and Library Journal, 5 (1), 22 - 32 . 
motivate myself to always learn and keep abreast of information, and encourage him to be able to create new information. Librarians should also further enhance the ability to utilize the latest resources and always follow the latest technological developments in order to facilitate the access to information in order to suit the needs and appropriate. Other than that, need to be made librarian at the Public Library forum Bogor City both formal and informal as a forum for knowledge sharing among librarians. It is also considering the information literacy skills they still have not been evenly distributed.

Leaders libraries should continue to motivate librarians and support the development of information literacy librarian competency. Leaders of the library can provide a reward and punishment to the results of the work done so librarians, so as to spur librarians to be able to constantly develop themselves. In addition, the Public Library of Bogor needs to conduct implementation, innovation in information literacy programs that already exist. For its implementation, should such activities not only for the students, but also for students and the general public. This activity needs to be conducted on an ongoing basis and can be widely disseminated. In advanced stages, at the library information literacy program implemented by more specific training and not only limited to the introduction of the library.

\section{References}

Armstrong, C., et al. (2005). CILIP defines Informatioan Literacy for the UK Library and Information Update, 4 (1), 22-25. Retrieved from http://www.cilip.org.uk/publications/ updatemagazine / archive / archive2005 / janfeb / armstrong.htm

Association of College and Research Libraries. (2000). Information Literacy Competency Standards for Higher Education. Retrieved from http://www.ala.org/acrl/sites/ ala.org.acrl / files / content / standards / standards.pdf

Catts, Ralph. (2010). UNESCO Information Literacy Indicators: Validation Report. United Kingdom: University of Stirling.

Chartered Institute of Library and Information Professionals. (2013). Information Literacy Definition. Retrieved from http://www.cilip.org.uk/cilip/advocacycampaignsawards/advocacy campaigns / informationliteracy / informationliteracy

Eisenberg, Michael B, et al. (2004). Information Literacy: Essential Skills for the Information Age. London: Libraries Unlimited.

Indonesia. (2007). Law of the Republic of Indonesia Number 43 Year 2007 About the Library. Jakarta: National Library.

----------. (2015). Regulation of the National Library of the Republic of Indonesia Number 11 Year 2015 Regarding Guidance Functional Librarian and credit figures. Jakarta: National Library.

City Government. (2018). Travel Event TOR Pustakaloka Bogor City Public Library Fiscal Year 2018. Bogor City Government.

Wicaksono, Arief. (2016). Profile Information Literacy Librarian Indonesia. Periodic Library and Information Science, 12 (1), 1-9.

Wijetunge, P. \& Alahakoon, U., (2009). Empowering 8: The Information Literacy models developed in Sri Lanka to underpin changing education paradigms of Sri Lanka. Sri Lankan Journal of Librarianship and Information Management, 1 (1), 31-41 Retrieved from http://dlib.pdn.ac.lk/bitstream/123456789/194/1/InformationLiteracy.pdf

Yaminfirooz, Mousa. (2013). Librarians 'Role in Development and Achievement of Central Library Users' Information Literacy (A Case Study: Iran). Sociomed Mater, 25 (4): 238.

To cite this document:

Hasanah, A., Rachman, M.A. (2019). Librarian's information literacy skills to fulfilling library

users' needs a public library in Bogor, Indonesia. Record and Library Journal, 5 (1), 22 - 32 . 